\title{
Zawał serca w przebiegu zatrucia tlenkiem węgla*
}

\author{
Myocardial infarction in the course of carbon monoxide poisoning
}

\author{
Paweł Kośmider, Iwona Gorczyca-Michta, Beata Wożakowska-Kapłon \\ ${ }^{1}$ I Klinika Kardiologii i Elektroterapii Świętokrzyskiego Centrum Kardiologii w Kielcach \\ ${ }^{2}$ Wydział Lekarski i Nauk o Zdrowiu Uniwersytetu Jana Kochanowskiego w Kielcach
}

\section{Streszczenie}

Zatrucie tlenkiem (CO) węgla jest częstą nieumyślną przyczyną zgonów. Kliniczna manifestacja intoksykacji to najczęściej objawy neurologiczne oraz kardiologiczne wynikające z niedotlenienia zarówno mózgu, jak i serca. Przedstawiono opis przypadku 55-letniego chorego z zawałem serca w przebiegu zatrucia CO.

Słowa kluczowe: zatrucie tlenkiem węgla, zawał serca, niedotlenienie, terapia hiperbaryczna

Folia Cardiologica 2017; 12, 4: 394-396

\section{Wstęp}

Zatrucie tlenkiem węgla (CO) jest jedną z najczęstszych przyczyn śmiertelnych zatruć w okresie jesienno-zimowym. Według statystyk Państwowej Straży Pożarnej w 2016 roku doszło do 3878 zatruć, spośród których 50 zakończyło się zgonem [1]. Przyczyną zatruć jest najczęściej wadliwa i niewłaściwie użytkowana instalacja grzewcza. Tlenek węgla to bezwonny gaz, który 250-300 razy silniej łączy się z hemoglobiną $(\mathrm{Hb})$ niż tlen, powodując hipoksję i niedotlenienie tkanek i narządów. Także przez łączenie się z oksydazą cytochromu C mitochondrium powoduje upośledzenie oddychania komórkowego i śmierć komórek [2]. Objawy zatrucia CO pojawiają się przy stężeniu 12\%, natomiast przy stężeniu powyżej $40 \%$ powoduje on zaburzenia świadomości do zgonu włącznie. U osób palących tytoń stężenie hemoglobiny tlenkowęglowej $(\mathrm{COHb})$ sięga 5\%, dlatego u nich nawet niewielkie i krótkotrwałe narażenie na CO może wywołać objawy zatrucia [3]. W niniejszym artykule zaprezentowano opis przypadku mężczyzny zatrutego CO, u którego wystąpił zawał serca typu 2.

\section{Opis przypadku}

Chory w wieku 55 lat, z przewlekłą chorobą nerek w 4. stadium, nadciśnieniem tętniczym i miażdżycą tętnic obwodowych, w godzinach wieczornych trafił na szpitalny oddział ratunkowy z powodu zasłabnięcia w domu. W badaniach laboratoryjnych stężenie $\mathrm{COHb}$ wynosiło $34,5 \mathrm{~g} / \mathrm{dl}$, a w gazometrii krwi tętniczej stwierdzono $\mathrm{pH}$ o wartości 7,26 oraz ciśnienie $\mathrm{pCO}_{2}$ równe $33 \mathrm{~mm} \mathrm{Hg} \mathrm{i} \mathrm{pO} \mathrm{O}_{2}$ równe $66 \mathrm{~mm} \mathrm{Hg}$. Czynność serca była miarowa i miała wartość około 110/min, a ciśnienie tętnicze wynosiło 157/80 mm Hg. Przy przyjęciu do szpitala chory nie zgłaszał dolegliwości stenokardialnych. Włączono tlenoterapię bierną. W pierwszych 48 godzinach hospitalizacji obserwowano dynamiczny wzrost wartości markerów niedokrwienia mięśnia sercowego (stężenie troponiny $T$ [TnT] do $1251 \mathrm{ng} / \mathrm{l})$. Dodatkowo u chorego stwierdzono hipercholesterolemię (stężenie cholesterolu całkowitego $218 \mathrm{mg} / \mathrm{dl}$, stężenie cholesterolu frakcji LDL [low-density lipoproteins] $121 \mathrm{md} / \mathrm{dl}$, stężenie cholesterolu frakcji HDL [high-density lipoproteins] $39 \mathrm{mg} / \mathrm{dl}$, stężenie cholesterolu non-HDL 179 mg/dl, wartość triglicerydów [TG] 170 mg/dl).

\footnotetext{
*Praca powstała w ramach projektu „Rola innowacyjnych systemów telemonitorowania w procesie wczesnej rehabilitacji kardiologicznej oraz powrocie chorego do pełnej aktywności fizycznej, psychicznej, społecznej i zawodowej”
} 


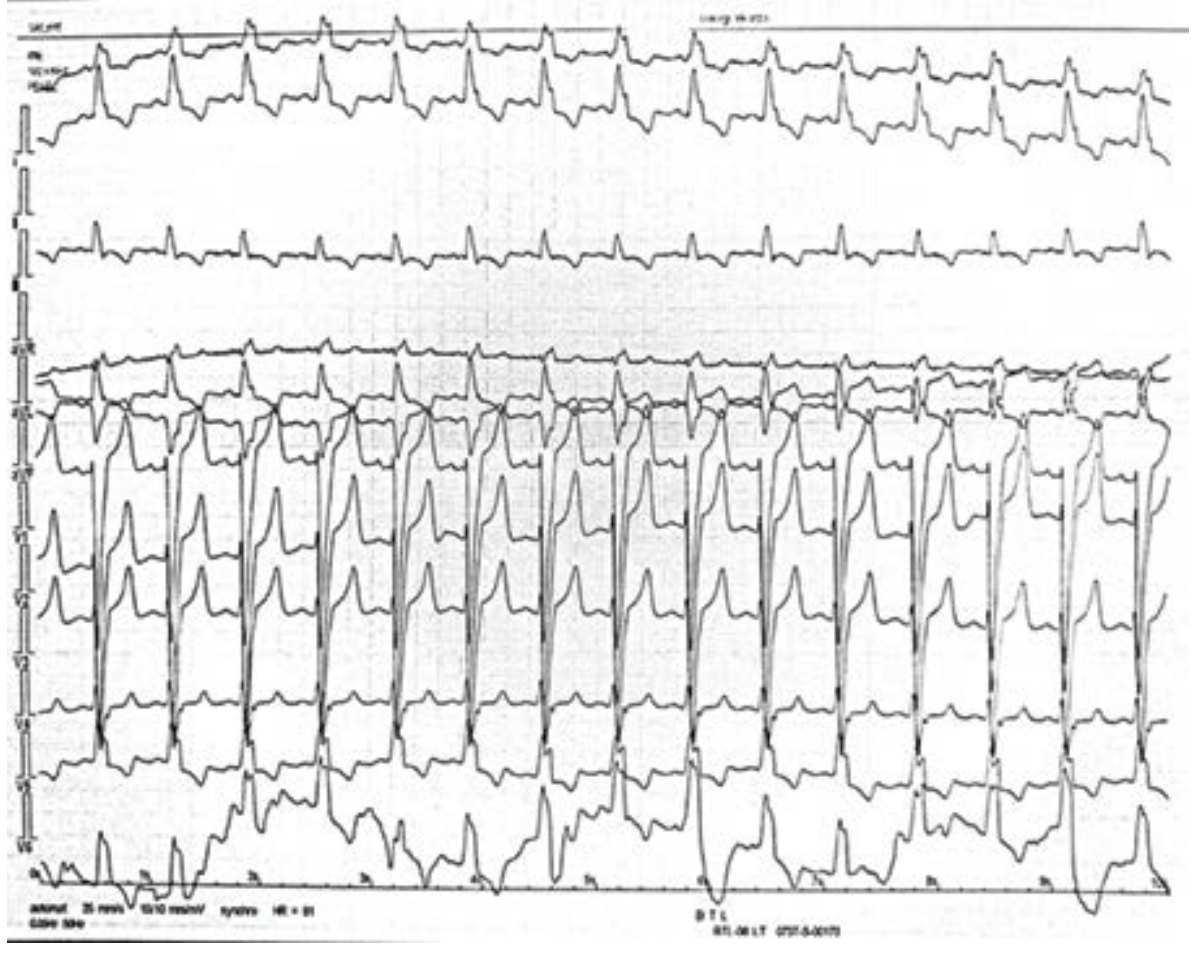

Rycina 1. Zapis z badania elektrokardiograficznego przy przyjęciu - obniżenie odcinka ST w odprowadzeniach II, III i aVF oraz blok lewej odnogi pęczka Hisa (LBBB, left bundle branch block) (przesuw $25 \mathrm{~mm} / \mathrm{s}$, cecha $10 \mathrm{~mm} / \mathrm{mV}$ )

W badaniu echokardiograficznym uwidoczniono akinezę przegrody międzykomorowej, podstawnego i środkowego segmentu ściany dolnej i przykoniuszkowego segmentu ściany przedniej. W badaniu elektrokardiograficznym (EKG) stwierdzono rytm zatokowy o częstości 66/min, blok lewej odnogi pęczka Hisa oraz ujemne załamki T w odprowadzeniach II, III i aVF (ryc. 1). W wykonanej w trybie pilnym koronarografii nie zobrazowano istotnych hemodynamicznie zmian. W leczeniu zastosowano kwas acetylosalicylowy, klopidogrel, atorwastatyne, bisoprolol, ramipril oraz allopurinol. Chorego wypisano do domu z zaleceniami profilaktyki chorób układu sercowo-naczyniowego oraz zalecono podwójne leczenie przeciwpłytkowe przez 12 miesięcy.

\section{Omówienie}

Jak już wspomniano, CO wykazuje co najmniej 250 razy większe powinowactwo do $\mathrm{Hb}$ niż tlen. Powoduje to łatwiejsze wiązanie się z $\mathrm{Hb}$ oraz wypieranie tlenu z połączeń $\mathrm{Hb}-\mathrm{O}_{2}$. Część wdychanego $\mathrm{CO}$ łączy się z białkami osocza, następnie z mitochondriami komórek, upośledzając proces oddychania komórkowego i prowadząc do ich śmierci [2]. Skutkiem zatrucia jest przede wszystkim hipoksja, na którą szczególnie wrażliwe są dzieci, osoby starsze oraz pacjenci z chorobami układu sercowo-naczyniowego. Czas połowiczej eliminacji $\mathrm{CO}$ wynosi około 90 minut w przypadku oddychania 100-procentowym tlenem oraz około 25 minut w przy- padku terapii w komorze hiperbarycznej [4]. U opisywanego chorego w 1. dobie hospitalizacji, gdy stężenie $\mathrm{HbCO}$ wynosiło $34,5 \mathrm{~g} / \mathrm{dl}$, doszło do wzrostu stężenia troponin sercowych (38,4 ng/l, 142,5 ng/l, 255,4 ng/l), co można tłumaczyć niedotleniem komórek miokardium w przebiegu hipoksji oraz zablokowaniem oksydazy cytochromowej C, której inhibicja trwa dłużej niż okres półtrwania $\mathrm{HbCO}$. Dodatkowo tachykardia zwiększała wydatek metaboliczny mięśnia sercowego, co mogło doprowadzić do rozwinięcia się niedokrwienia mięśnia sercowego. Obraz kliniczny chorego pozwalał na rozpoznanie zawału serca typu 2 zgodnie ze stanowiskiem European Society of Cardiology/American College of Cardiology/American Heart Association (ESC/ /ACC/AHA) z 2012 roku [5]. W wykonanej koronarografii nie uwidoczniono istotnych hemodynamicznie zmian, co pozwoliło na rozpoznanie zawału serca typu 2. Satran i wsp. [6] donoszą, że podwyższone stężenie troponiny oraz zmiany w EKG mogą być obecne u 37\% osób zatrutych CO. U każdego chorego z podejrzeniem intoksykacji CO należy wykonać 12-odprowadzeniowe EKG oraz oznaczyć markery martwicy mięśnia sercowego. $Z$ literatury znane są opisy chorych z zawałem serca w przebiegu zatrucia CO [7, 8]. W długoterminowej obserwacji 230 osób Henry i wsp. [9] zauważyli, że zatrucie CO predysponowało do zwiększonej umieralności z przyczyn sercowo-naczyniowych w porównaniu z populacją niepoddaną narażeniu na tę substancję. Wystąpienie kardiologicznych objawów zatrucia CO oznacza 
ciężką postać intoksykacji i wskazuje na konieczność leczenia tlenem hiperbarycznym. Trudności w leczeniu hiperbarycznym w Polsce wynikają z małej liczy ośrodków dysponujących komorą hiperbaryczną.

Ze względu na nierzadkie przypadki zatruć CO w Polsce z często towarzyszącymi objawami kardiologicznymi autorzy uznali, że przypadek opisanego chorego zasługuje na omówienie.

\section{Konflikt interesów}

Autorzy nie zgłaszają konfliktu interesów.

\section{Abstract}

Carbon monoxide (CO) poisoning is a common, unintentional cause of death. The clinical manifestation of intoxication is most often neurological and cardiovascular symptoms of hypoxia in both the brain and the heart. A case report of a 55-year-old patient with myocardial infarct in the course of $\mathrm{CO}$ poisoning was presented.

Key words: carbon monoxide poisoning, myocardial infarct, hypoxia, hyperbaric oxygen therapy

Folia Cardiologica 2017; 12, 4: 394-396

\section{Piśmiennictwo}

1. http://www.straz.gov.pl/porady/Sezon_grzewczy_2015_2016. 2017.

2. Alonso JR, Cardellach F, López S, et al. Carbon monoxide specifically inhibits cytochrome $c$ oxidase of human mitochondrial respiratory chain. Pharmacol Toxicol. 2003; 93(3): 142-146, indexed in Pubmed: 12969439.

3. Thom SR. Carbon monoxide pathophysiology and treatment. In: Neuman TS, Thom S. ed. Physiology and medicine of hyperbaric oxygen therapy. Elsevier Inc., Philadelphia 2008: 321-347.

4. Rucker J, Fisher JA. Carbon monoxide poisoning. In: Albert RK, Slutsky AS, Ranieri VM. et al. ed. Clinical critical care medicine. Philadelphia, Elsevier Inc. 2006: 679-683.

5. Thygesen K, Alpert JS, Jaffe AS, et al. Trzecia uniwersalna definicja zawału serca. Kardiol Pol. 2012; 70(Suppl V): S235-S254.
6. Satran D, Christopher H, Adkinson C, et al. Cardiovascular manifestiations of moderate to severe carbon monoxide poisoning. J Am Coll Cardiol. 2005; 45(9): 1513-1516, doi: 10.1016/j.jacc.2005.01.044, indexed in Pubmed: 15862427.

7. Gawlikowski T, Groszek B, Urbanik A. Ciężkie zatrucie tlenkiem węgla: różny przebieg kliniczny - to samo źródło narażenia. Przegl Lek. 2001; 58: 354.

8. Sielski J, Stern A, Ciuraszkiewicz K, et al. Zawał serca u mężczyzny zatrutego tlenkiem węgla. Kardiol Pol. 2009; 67(10): 1107-1109.

9. Henry CR, Satran D, Lindgren B, et al. Myocardial injury and long-term mortality following moderate to severe carbon monoxide poisoning. JAMA. 2006; 295(4): 398-402, doi: 10.1001/jama.295.4.398, indexed in Pubmed: 16434630. 